\title{
Fulminant hepatic failure caused by herbal supplies
}

\author{
Genário Oliveira Santos Júnior ${ }^{2 *}$, Raymundo Paraná Ferreira Filho ${ }^{1}$, Liana Machado de Codes \\ Foulon $^{2}$, Lúcia de Araújo Costa Beisl Noblat ${ }^{3}$
}

\author{
${ }^{1}$ Medical School, Federal University of Bahia, Salvador, Bahia, Brazil, ${ }^{2}$ Gastroenterology and Hepatology Service of \\ University Hospital Professor Edgard Santos, Federal University of Bahia, Salvador, Bahia,Brazil, ${ }^{3}$ Pharmacy School, Federal \\ University of Bahia, Salvador, Bahia, Brazil
}

\begin{abstract}
The consumption of botanicals for therapeutic purposes has increased significantly in recent years. Druginduced liver disease (DILI) is a frequent cause of acute liver injury, around $50 \%$ in the United States, and about $1 \%$ is secondary to the use of phytotherapeuticals and herbal supplies. Ruellia bahiensis, a plant species of the Acanthaceae family, is a tropical plant distributed in Northeastern Brazil. In folk medicine in the state of Bahia, the species is known as "mãe-boa" and is commonly used. L.S.S, a 23-year old, female, patient was admitted at University Hospital of Bahia-Brazil with signs and symptoms of acute hepatitis. She had made daily use of an herbal supply popularly known as "mãe-boa" for at least two years prescribed by a physician. Diagnostic investigation was negative for viral and autoimmune hepatitis, leptospirosis, dengue, and CMV (cytomegalovirus). The patient had to undergo liver transplantation. Explant revealed massive hepatic necrosis. According to histological findings, and after exclusion of other etiologies, liver damage was assigned to herbal supply. The prolonged use of Ruellia bahiensis infusions may have caused the liver dysfunction.
\end{abstract}

Keywords: Liver failure/study. Liver transplantation. Acute. Herbal Medicine.

\section{INTRODUCTION}

The consumption of botanical agents for therapeutic purposes has grown exponentially in recent years in western countries (Veiga, Pinto, 2005). A recent study reveals that $42 \%$ of North Americans experience some form of alternative health care treatment, $12.5 \%$ of them make use of herbal agents and, in the last ten years, they accounted for $20 \%$ to $30 \%$ of patients with clinical liver injuries in health care services (Estes et al., 2003).

In the United States, it is estimated that approximately 2,000 people per year are diagnosed with fulminant hepatic failure (FHF): $13 \%$ of them due to idiosyncratic adverse reactions to drugs, while 10 to $22 / 1,000,000$ hospitalizations/per year are related to idiopathic hepatitis (Ostapowicz et al., 2002).

A research conducted by Dhiman et al. (1998) studied 204 patients diagnosed with acute liver failure. Among these, 15 (7.4\%) suffered from DILI. Another

\footnotetext{
*Correspondence: G. O. Santos Júnior. Hospital Universitário Prof. Edgard Santos. Rua Augusto Viana, S/N, Canela, 40110-060 Salvador, Bahia. E-mail: genariofarma@yahoo.com.br
}

study conducted in India, comprising 430 patients with FHF, demonstrated that $4.5 \%(19 / 430)$ of the cases were related to drugs (Acharya et al., 1996). In a series of 20 patients with FHF referred to liver transplantation, $35 \%$ of cases had no identified cause other than herbal supplement use (Estes et al., 2003).

The mechanism by which herbal and phytotherapeutic agents cause liver damage is unclear. Drugs and chemical agents may act as direct hepatotoxins or the injury may be the result of idiosyncratic inflammatory reactions (Goldman, Auselio, 2005). A single drug can trigger toxic effects through different mechanisms. Although the toxicity of certain drugs is dose-related, the idiosyncratic drug-induced toxicity suggests marked environmental and host-related factors, such as age, use of alcoholic beverages, gender, preexisting liver and/or kidney diseases and genetic factors, such as enzymatic polymorphism. The genetically different isozymes of cytochrome (CYP) P450 may partially explain the varied drug response (Schidt, Lee, 2005).

One of the probable mechanisms can be explained by biotransformation, which generally modifies a non-polar in a polar compound, followed by oxidative 
pathways mediated by cytochromes (CYP) P-450. Another mechanism by which hepatotoxicity may occur would be through the involvement of glutathione $S$-transferase acetylating and alcohol dehydrogenase enzymes (Schidt, Lee, 2005).

The clinical features of severe hepatic failure are varied, which comprise hepatic encephalopathy, jaundice, coagulopathy, renal and circulatory dysfunction, hyperammonaemia (Keeffe, 2005).

In popular and traditional Brazilian medicine, and more specifically in the state of Bahia (northeast Brazil), a plant popularly known as "mãe-boa" is usually intended for women. It is used as an anti-inflammatory agent for the treatment of female genital tract diseases. Mãe-boa was identified as Ruellia bahiensis, a plant that belongs to the acanthaceae family. The genus Ruellia L. comprises about 150 species native to tropical and temperate North and South America (Da Silva et al., 2005). The well-recognized groups of secondary metabolites are flavonoids, lignans, coumarins, alkaloids, among others (Samy et al., 2015).

We hereafter describe a case of a young woman who has made continuous use of Ruellia bahiensis and ended up developing hepatic dysfunction, which required liver transplantation.

\section{Case report}

A 23-year-old black female patient sought medical care complaining of abdominal pain, diaphoresis, nausea, and headaches. She denied the usage of illicit drugs but reported drinking on weekends and smoking occasionally. Moreover, she reported having seafood allergy.

She took oral contraceptive (levonorgestrel 0.15 $\mathrm{mg}+$ ethinyl estradiol $0.03 \mathrm{mg}$ ) 4 years ago; 1 pill of prednisone a day upon seafood consumption. She reported sporadic use of acetylsalicylic acid and dipyrone for headaches. Regarding the use of herbal supplies, she sporadically ingested infusions of Peumus boldus (Chilean boldo) and Piper umbellatum (capeba) for abdominal pains during the last 3 months, as well as Ruellia bahiensis for 5 months.

On physical examination, the patient was markedly icteric, and reported to have abdominal pain, sweating, nausea, headaches, and drowsiness. Laboratory tests workup revealed $\mathrm{AST}=1201 \mathrm{U} / \mathrm{L}$ (reference value $[\mathrm{RV}]=15-50 \mathrm{U} / \mathrm{L}), \mathrm{ALT}=1290 \mathrm{U} / \mathrm{L}(\mathrm{RV}=15-47 \mathrm{U} / \mathrm{L})$, total bilirubin of $21.78 \mathrm{mg} / \mathrm{dL}(\mathrm{RV} \leq 1,10 \mathrm{mg} / \mathrm{dL})$ ), INR (international normalized ratio) of $2.31(\mathrm{RV} \leq 1,2)$ and prothrombin time of $28 \%$ ( $R V \geq 70 \%)$. Additionally, the patient tested negative for: IgM Anti-HBc, HBsAg,
Anti-HAV (IgM), Anti-HCV, Toxoplasmosis IgM, Cytomegalovirus IgM, leptospirosis IgM, dengue IgM, Herpes I and II (IgM), HIV I and II, Anti-nuclear Factor - anti smooth muscle, anti-LKM and antimitochondrial antibodies.

The patient's clinical status worsened after hospitalization with signs of acute liver failure. Two days after admission, the patient was submitted to orthotopic liver transplant. The histopathology of the explanted liver revealed extensive multilobular necrosis, with many apoptotic bodies. A mild mononuclear inflammatory infiltrate containing lymphocytes, few plasma cells and macrophages was observed. The bile duct had no injuries.

Considering the aforementioned drugs, an interaction between the oral contraceptive and prednisone was identified, so that the contraceptive potentiates the effects of the corticosteroid (neurophysiological reactions, electrolyte disorders, hypertension, hyperglycemia), but no relation to liver damage could be found. Moreover, no interaction between Ruellia bahiensis vs. oral contraceptive and Ruellia bahiensis vs. prednisone has been described.

With regard to Piper umbellatum and Peumus boldus, there are reports in the literature showing the association of these herbal infusions with hepatotoxicity. However, the patient used those herbs after the onset of signs and symptoms of FHF. According to Teschke, Schwarzenboeck and Hennermann's algorithm (2008), causality between FHF and infusions of Ruellia bahiensis was possible.

\section{DISCUSSION}

This is the first reported and documented case of Fulminant Hepatic Failure probably caused by the use of Ruellia bahiensis infusions. According to studies, the use of botanical infusions for therapeutic purposes and the development of DILI secondary to herbal supplies are more frequently observed amongst women (Estes et al., 2003). The clinical features presented by the patient described are typical of fulminant hepatic failure, as corroborated by the laboratory tests and further anatomopathologic examination (Powel, 2005).

The viral serologies are essential in these cases, since the exposure to viral hepatitis A in Brazilian population is still high. The prevalence for hepatitis B is of $1 \%$ and for hepatitis C, $2 \%$. However, these possibilities as well as other viral serologies were ruled out in our patient (Ferreira, Silveira, 2004), as they tested negative.

Autoimmune hepatitis is characterized by the presence of autoantibodies, high levels of serum 
immunoglobulins and frequent association with other autoimmune diseases (Lindsay, Hoofnagle, 2005). The diagnosis of autoimmune hepatitis is also based on histological findings. In the case reported, the histological findings were not consistent with this diagnosis, but with a toxic etiology aggression process.

Other causes of fulminant hepatitis, such as Budd-Chiari syndrome, Wilson's disease and Reye's syndrome, were excluded because the patient's clinical outcome and laboratory tests did not characterize any of the aforementioned etiologies (Belay et al., 1990). Other disorders that may lead to FHF, such as fatty liver of pregnancy, hyperthermia, hypoxia, malignant infiltration and sepsis were also excluded (Goldman, Auselio, 2005).

Regarding the use of allopathic drugs, it is estimated that the chemical or drug-induced toxicity is associated with $25 \%$ to $30 \%$ of hepatopathy cases (Lindsay et al., 2005). Among the drugs used by the patient, the oral contraceptive (levonorgestrel + ethinyl estradiol) should be taken into consideration, since it presents the ability to contribute to liver damage, especially complications of cholestasis, as described by Scheuer (1974). However, according to histological results, damage caused by steroids is mischaracterized, as it is defined by cholestasis (dilated canaliculi, brown granules in the cytoplasm of hepatocytes), some level of hepatic cell necrosis, lesions of the biliary ducts lesions, and polymorphonuclear leukocyte infiltration (Bhamidimarri, Schiff, 2013).

From the results obtained after botanical identification of plant species, it is possible that the species responsible for the patient's liver damage was Ruellia bahiensis. With regard to the use of other concomitant herbal infusions with Ruellia bahiensis, Peumus boldus was reported to be associated with the elevation of aminotransferases (Ruiz et al., 2008). However, in the reported case, Peumus boldus was not ingested daily and the beginning of its intake occurred after the onset of liver toxicity symptoms.

There has been no evidence regarding toxicity of Ruellia bahiensis and its association with fulminant hepatic failure. However, the patient's habits of using herbal supplies may be an indicative of the occurrence of the damage, since the idiosyncratic drug-induced toxicity suggests important environmental and host-related factors, such as age, alcohol use, sex, preexisting hepatic disease, kidney disease and genetic factors, such as enzymatic polymorphism (Schidt, Lee, 2005).

As for the causality assessment between the possible use of Ruellia bahiensis infusions and FHF, the result obtained by applying the algorithms was classified as possible according to Teschke, Schwarzenboeck,
Hennermann (2008). This result can be explained by the fact that some variables of this algorithm, such as the assessment of plasma drug concentration or the use of placebo for the evaluation of the use of herbal supplies are not part of routine health services activities in Brazil.

One of the proposals of the Teschke, Schwarzenboeck and Hennermann's (2008) algorithm is that it questions the existence of Anti-HVE tests. However, even in our case, the fact that this test was not carried out is not of major importance, since epidemiological data do not suggest a relevant frequency of Hepatitis E in the country at issue. Another proposal raised in this algorithm is the reexposure of the patient to the drug. This is not applicable in our case either because the outcome of the reaction does not enable this analysis.

Acute liver failure is likely to affect the patient and is related to the use of Ruellia bahiensis, although fulminant hepatic failure secondary to the use of phytotherapeuticals is related to $1 \%$ of cases (Estes et al., 2003). This small percentage is associated with the absence of pharmacovigilance studies on herbal infusions, phytotherapy, which reflects the lack of research and knowledge about the use of plants and their relationship as an etiological agent for DILI cases. Therefore, the report indicates the relevance of advising patients that natural supplements are not harmless to health.

\section{REFERENCES}

Acharya SK, Dasarathy S, Kumer TL, Sushma S, Uma Prasanna KS, Tandon A, et al. Fulminant hepatitis in a tropical population: clinical course, cause, and early predictors of outcome. Hepatology. 1996; 23(6):1448-55.

Belay ED, Bresee JS, Holman RC, Khan AS, Shahriari A, Schonberger LB. Reye's syndrome in the United States from 1981 through 1997. N Engl J Med. 1990;340:1377- 82.

Bhamidimarri KR, Schiff E. Drug-induced cholestasis. Clin Liver Dis. 2013;17(4):519-531.

Da Silva MJ, De Melo, JIM; De Sales, MF. Flora da região de Xingó, Alagoas e Sergipe: acantaceae a. juss. Rev Caatinga. 2005;23(2):59-67.

Dhiman RK, Eth AK, Jain S, Chawla YK, Dilawari JB. Prognostic evaluation of early indicators in fulminant hepatic failure by multivariate analysis Dig Dis Sci.1998;43(6):1311-6. 
Estes JD, Stolpman D, Olyaei A, Corless CL, Ham JM, Schwartz JM, Orloff SL. High prevalence of potentially hepatotoxic herbal supplement use in patients with fulminant hepatic failure. Arch Surg. 2003;138(8):852-858.

Ferreira CT, Silveira TR. Hepatites virais: aspectos da epidemiologia e da prevenção. Rev. Bras. Epidemiol. 2004;7(4):473-87.

Goldman L, Auselio D (editores). Cecil - Tratado de medicina interna: Insuficiência hepática e transplante de fígado. Rio de Janeiro: Elsevier, 2005.

Keeffe EB. Insuficiência hepática e transplante de fígado. In: Lee Goldman L, Ausiello D, editors. Tratado de medicina interna. 22 ed. Rio de Janeiro: Elsevier; 2005. p. 1093.

Lindsay KL, Hoofnagle JH. Hepatite Crônica. In: Lee Goldman L, Ausiello D, editors. Tratado de medicina interna. 22 ed. Rio de Janiero: Elsevier; 2005. p. 1069.

Ostapowicz G, Fontana RJ, Schiodt FV, Larson A, Davern TJ, Han $\mathrm{SH}$, et al. Results of a prospective study of acute liver failure at 17 tertiary care centers in the United States. Ann Intern Med. 2002;137(12):947-54.

Powel DW. Abordagem do paciente com doença hepática. In: Lee Goldman L, Ausiello D, editors. Tratado de medicina interna. 22 ed. Rio de Janeiro: Elsevier; 2005. p.1034.
Ruiz AL, Taffarello D, Souza VHS, Carvalho JE. Farmacologia e toxicologia de Peumus boldus e Baccharis genistelloides. Rev Bras Farmacogn. 2008;18(2):295-300.

Samy MN, Sugimoto S, Matsunami K, Otsuka H, Kamel MS. Chemical constituents and biological activities of genus Ruellia. Int J Pharmacogn. 2015;2(6):270-279.

Scheuer PJ. Long-term effects on the liver. J Clin Pathol.1974;28:71-74.

Schidt FV, Lee WM. Doença Hepática induzida por produtos tóxicos, medicamentos e outras substâncias. In: Goldman L, Ausiello D, editors. Tratado de medicina interna. 22 ed. Rio de Janeiro: Elsevier; 2005. p. 1048.

Teschke R, Schwarzenboeck A, Hennermann KH. Causality assessment in hepatotoxicity by drugs and dietary supplements. Br J Clin Pharmacol. 2008; 66(6):758-66.

Veiga Jr. VF, Pinto CA. Plantas medicinais: cura segura? Quim Nova. 2005;28(3):519-528.

Received for publication on $19^{\text {th }}$ July 2017 Accepted for publication on $20^{\text {th }}$ October 2017 